УДК: 1(091)111.84

DOI $10.35423 / 2078-8142.2018 .3-4.08$ \section{старший викладач Луганського обласного інституту \\ ОНТОЛОГІЯ ДОБРА І ЗЛА В КОНТЕКСТІ ФІЛОСОФІЇ М.БУБЕРА: ПОШУК ДІАЛОГУ МІЖ БОГОМ І ЛЮДИНОЮ}

Г. І. Савонова, кандидат філософських наук, післядипломної педагогічної освіти, м. Сєвєродонецьк, Украӥна ORCID: https://orcid.org/0000-0003-1790-4770

У статті піднімається та досліджується питання визначення онтології добра $і$ зла в філософії М. Бубера. Пошук онтології добрі зла пропускається через три базові складові філософії М. Бубера: діалогове вимірювання стосунків людини з позииії «Я Ти», «Я - Воно»; християно-юдейської специфріки визначення сутності Бога щуодо появи зла в світі; розкриття сенсі віри в житті людини та спілкуванні з Богом. Визначається важливість налагоджування спілкування людини з Богом з позииії «Я - Ти», коли теодищея не матиме важливості для людини, щуо вірить. Розкривається специфіка будування питання онтологї зла згідно християнським і хасидським тлумаченням. Звертається увага на хід міркування М. Бубера щзодо онтології добра $і$ зла та ї̈ розкритті в сиені гріхопадіння людини відповідно до Біблейського тексту. Робиться висновок щчодо творіння добра $і$ зла як першоідей Богом, щуо й стає джерелом добра $і$ зла.

Ключові слова: добро $і$ зло, Бог, діалог, віра, «Я - Ти», «ЯВоно», дуалізм.

Поняття добро і зло як моральні та релігійні імперативи постійно перебувають у центрі уваги філософів. За різних історичних часів та на різних географічних площинах людство по-різному пояснювало їх сутність та причини виникнення, змінювався підхід до відповідальності людини щодо іï вчинків. Із розвитком цивілізацій

(C) Савонова Г. І., 2018 
самі поняття доповнювалися визначеннями, а дітей навчали, спираючись на розуміння того, що є добрим, а що поганим. М. Бубер підмітив цю тенденцію розвитку образів добра і зла в соціумі саме через спілкування та висвітив новий підхід у проблемі онтології добра і зла, а саме - діалоговий принцип побудови світу. Деякі дослідники вважають його філософію дещо «наївною», «дитячою», інші вбачають у цьому нові соціально-педагогічні технології, але й ті й інші не заперечують той внесок, який зробив М. Бубер у розвиток сучасної філософської антропології.

Із філософською спадщиною М. Бубера вітчизняні дослідники мали змогу ознайомитися тільки з розпадом Радянського Союзу. На жаль, для багатьох дослідників його ім'я було затьмарено іншими відомими представниками філософії екзистенціалістів М. Гайдеггером, Ж.-П. Сартром, А. Камю, К. Ясперсом, Г. Марселя та ін. Саме тому філософське вчення М. Бубера й досить залишається мало вивченим на теренах пострадянських країн. До того ж, наразі, не всі твори філософа були перекладені на російську мову, а тим паче на українську. Тим не менш, можна назвати прізвища тих дослідників, хто звертався до філософської спадщини М. Бубера як частково заради дослідження певного категорійного імперативу чи явища - П. С. Гуревич, А. П. Огурцов, Л. І. Василенко, так і тих, хто в цілому опікувався дослідженням філософії М. Бубера Т. П. Ліфінцева, Р. В. Костенко, А. В. Ахутін.

Співвідношення діалогу та розмаїття уявлень про об’єктивність буття - головна тема філософії М. Бубера. Саме до неї звертається більшість дослідників. Так, А. В. Ахутін, розглядаючи парність слів у філософії М. Бубера, проводить паралель між Біблійними історіями творення світу та поділом цілісного виміру «Ти» на вимір «Я - Ти», «Я - Воно». Більш детально питання метафізики буття у філософії М. Бубера розглядає Т. П. Ліфінцева. Дослідниця співвідносить філософське вчення М. Бубера 3 іншими екзистенціалістами, а особливо з М. Гайдеггером, для якого лінгвістичні особливості людської мови також мали велике значення в питанні структури буття та рівнів можливості його визначення людиною. Г. С. Померанц цікавиться особистим досвідом спілкування 
філософа з релігійними людьми чи представниками церкви, та прагне в цьому віднайти основу його філософсько-релігійного вчення.

Отже, метою статті є визначення специфіки онтології добра і зла та концепції діалогу в християнсько-іудейській філософії М. Бубера. Виходячи із зазначеного базовими завданями дослідження $є$ : 1) розкриття діалогової структури світу з точки зору М. Бубера; 2) встановлення ролі віри у спілкуванні людини та Бога на моральних засадах; 3) створення моделі онтології світу з урахуванням діалогової концепції філософії М. Бубера.

Уявлення про двоякість світу виникає ще на зорі людського існування, коли людина починала відокремлювати світ живих від світу духів, світ богів - від світу людей, світ природи - від світу неживої матерії. Поступово дуалізм стає головною особливістю людської екзистенції, мірою мислення, і вже не виникає сумнівів у дуалізмі всього, що існує та навіть того, що є неіснуючим у бутті. М. Бубер у творі «Я і Ти» відзначає: «Світ дуалістичний для людини в силу дуалістичності його співвіднесення з ним» [7, с. 24]. Постає питання, в чому проявляється цей дуалізм. Якщо, наприклад, Платон поділяв світ на світ реальний і світ ідей, Августин Аврелій - на град земний та град небесний, А. Шопенгауер - на світ, який уявляємо та світ, який воліємо, то у М. Бубера дуалізм світу спирається на парність слів, що є наслідком діалогу.

У філософському словнику ми знаходимо таке розуміння діалогу. «Діалог - це філософський термін, який використовується в сучасних онтологічних теоріях комунікації для визначення особливого рівня комунікативного процесу, на якому відбувається злиття особистостей учасників комунікації» [10, с. 244]. Тобто діалог - це процес, але процес завжди є кінцевим результатом чогось важливого: потреби, свободи, духовної наснаги тощо. А отже, онтологія буття не може полягати в його кінцевості, і М. Бубер це розумів. В екзистенціальній філософії М. Бубера буття являє собою діалог, а парність слів є яскравим проявом поліфонічності дуалізму буття.

А. В. Ахутін вбачає в парності слів М. Бубера онтологію буття. «За Бубером, «Я - Ти» і містить власне первісне відношення, єдине першослово, яке слід припустити на початку (в початку). «На 
початку було слово». Це дивне першослово: Я - Ти. Це першовідношення. Першовідношення є відношення спілкування. На початку $\epsilon$ (було, буде) спілкування. Усе інше підзвітне цьому початку. Усе інше - модуси, метаморфози, забуття цього первоначалу, градуси охолодження первісного спілкування» [1, с. 611].

Відомий дослідник праць екзистенціалістів Г. С. Померанц зазначив, що структура діалогу М. Бубера спирається на поняття «мати» та «бути» [9]. Поняття «мати», властиве діалогу Я - Воно, $\epsilon$ проявом фізичного відношення людини до світу, тобто відношення на засадах користування навколишніми речами задля власних потреб. Поняття «бути», властиве діалогу Я - Ти, є проявом духовного стану людини, фактично проявом його цілісного існування в бутті. Для людини більш важливим є будування власної екзистенції в синтезі мовчазного діалогу «Я - Ти», тобто в трансценденції здійснення комунікації без поглиблення в неї, можливість спілкуватися мовчки, повернувшись спинами один до одного. Бо тільки так здійснюється справжній діалог. Проте людина частіше занурена в ситуацію дистанції діалогу «Я - Воно». Такий діалог відтягує людину від діалогу «Я - Ти», де обидва учасники вступають до спілкування як рівні, вільні, здатні пізнавати сторони.

Цікавим є та супротивність, що виникає у принципі діалогової структури побудови світу. Адже конструкція діалогу відразу вимагає від екзистенції буття людини визнання поліфонічної побудови світу на принципах дуалізму, де існують крайні протилежності, між якими відбувається існування людини, і сама людина роздвоюється в діалогових стосунках зі світом, як світом - Ти та світом - Воно, буттям, що є відразу ворожим людині, й буттям, що $є$ союзником людини. У цьому роздвоєнні відбуваються крайнощі добра і зла, любові та ненависті, щастя та горя тощо. При чому ці категорії, якими звикла користуватися людина, отримують власне монофонічне буття. Тобто в царстві добра немає зла, в царстві Бога немає диявола, в царстві віри немає безвір'я. Поєднання цих царств відбувається в людині, як ті плоди древа пізнання добра і зла, що змішалися тільки тоді, коли людина їх скуштувала. 
Водночас діалогова структура світу, сформована М. Бубером, вказує на цільність буття. Цю цільність підкреслює перша частина діалогу - частина Я. «Немає Я самого по собі, є тільки Я основного слова Я - Ти та Я основного слова Я - Воно. Коли людина каже Я, вона має на увазі одне із них. Я, яке вона має на увазі, присутнє, коли вона говорить Я» [7, с. 24-25].Поняття Я еквівалентне поняттю особистого буття. Буття не може бути частковим, адже не можна наполовину існувати, наполовину не існувати. Згідно $з$ філософією М. Бубера, неправильне розуміння цілісності буття призводить до неправильного пошуку онтології буття. Відокремлення поняття «мати» від поняття «буття» призводить до намагань віднайти онтологію частини цілого за межами цілого. Так, визначаючи Бога онтологією добра, мислителі століттями намагаються відмежувати Бога від зла і спотикаються на тому, що теодицея неможлива за апріорного твердження Бога як Творця буття, адже в цьому бутті icнує зло як самостійна екзистенція та як дія оцінювання в діалоговому світі людини. Фактично, виникає потреба або визнати Бога винним у створенні зла, а це призводить до іншого - пошуку в злі божественного духу, або відмовити Богові у творінні світу, тоді постає питання - який же Він тоді Бог. М. Бубер як раз не бачить проблеми в ситуації визнання божественної онтології і добра, i зла. Інше питання, хто розвів ці поняття в різні боки. Пошуки відповіді філософ пропонує шукати в Торі та відновленні втраченого діалогу людини з Богом.

М. Бубер виокремлює три різновиду діалогу: дійсний, технічний та монолог. Дійсний діалог - це діалог спостереження, визнання існування іншого в бутті. Дійсний діалог як діалог візуалізації базується на мовних правилах та відбувається в часово-просторовій площині. До форми дійсного діалогу людина прибігає найчастіше, використовуючи його в повсякденному житті. Дійсний діалог - це ілюзія людської спільноти, єдності усіх, перевтілення усіх «Воно» в «Ти», часто він виступає видимістю втечі від самотності, не сприйняття іншими.

Технічний діалог можна було б ще назвати діалогом офіційного мовлення. Цей діалог, не здатний захистити людину від само- 
тності, намагається, розробляючи правила спілкування, зменшити конфліктність непорозумінь між людьми та абстрагуватися від суб'єктивних умовиводів, надати усьому, що відбувається, об'єктивне розуміння та визнання права на існування без заперечності права іншого. Технічний діалог фактично є основою взаємовідносин людей у призмі техніки та комп'ютеризації людського життя, базою віртуальної культури. Але не технічний, не дійсний діалоги не в змозі дати людині те, що вона справді потребує - повне розуміння іншим, яке не потребуватиме виправдань, та й взагалі спілкування. Найвищим рівнем діалогу М. Бубер вважатиме монолог, тобто сумісне мовчання. «Діалогічне існування знаходить навіть у крайній самотності глибинне передчуття взаємності, що дає йому сили; монологічне - навіть у ніжному спілкуванні не виходить за межі своєї самості» [4, с. 142]. Умовою для істинного діалогу є усвідомлення інакшості Іншого. Філософ вважає, що це відчуття доступне кожному, коли «Ти» залишається «Ти», а не перевтілюється на «Воно». Цей діалог - це діалог відношень, світ зустрічі людини 3 іншою екзистенцією, це буття між «Я» і «Ти». У цьому діалозі головним буде «Ти», а не «Я», бо щоразу, коли Я передує, «Ти» щезає, залишаючи тільки «Воно».

М. Бубер виокремлює три сфери, в межах яких будується діалог. Перша: життя 3 природою, де відношення коливаються до мови. Друга: життя з людьми, де відношення візуальні та оформлені в межах мови, навіть мови із власним «Я» від імені мого уявлення про «Ти». На цьому рівні людина може давати власне і розуміти інше «Ти». І третя сфера: життя з духовними істотами після мови. Такі відношення не явні, вони покриті таємницею монологового спілкування, вони не мають мови, але породжують їі, відбиваючись у молитвах та обрядах.

Цікавим є те, що М. Бубер вважає діалог первинним, а усвідомлення своєї екзистенції вторинним, породженим із діалогу. Діалог породжує уособлення, а потім змінюється під його впливом. Людина не в змозі впливати на ці зміни, утримувати біля себе «Ти», як не в змозі постійно перебувати в теперішньому, що є лише коротка миттєвість відчуття свободи. Саме в теперішньому щезає віч- 
ність, але завжди є той монолог, який повертає іiі до людини - вічний діалог з Богом.

Своє відношення до Бога М. Бубер стисло виразив такими речами: «Якщо віра в Бога означає здатність говорити про Нього в третьому лиці, то я не вірю в Бога. Якщо віра в Бога означає здатність говорити з Ним, то я вірю в Бога» [3, с. 302]. Таким чином, філософ чітко підкреслив позицію віри стосовно Бога, а не позицію міркування про нього. Людині немає потреби шукати Бога, аналізувати його, розмірковувати про нього. У міркуванні про Бога з'являється багато питань, на які людина не в змозі дати відповіді, й тоді вона сама починає підточувати свою віру, втрачати Бога як «Ти».

Одкровення М. Бубер розуміє як покликання та покладання місії на людину. Одкровення - це не просто книга, а реальна зміна, що виникає в людині завдяки подіям, зустрічам. Коли людина зустрічає «Ти», вона починає розуміти своє покликання. Зустріч з Богом - найбільше бажання людини. Коли це відбувається, людина починає розуміти свою місію, питання про сенс життя знімається. Яскравим прикладом такої зустрічі є клінічна смерть людини, короткочасна смерть, що є станом виходу людини із буття та потрапляння в небуття зустрічі з Богом - Ти.

Серйозне значення отримує діалог у тому випадку, коли людина шукає Бога. Бог може бути присутнім у людському діалозі й тим самим бути свідком для людей про істину цього діалогу. У Біблії Святий Дух свідчить відносини Батька і Сина. Це справжній діалог любові, тому що Батько відкриває Свою любов до Сина, який відповідає такою самою любов'ю. Любов Отця і Сина може розкритися для того, хто шукає Бога і вірує в Христа. Справжність діалогу між Батьком і Сином стає очевидним для людини, що вірить, оскільки Святий Дух свідчить йому відносини Батька і Сина. Хоча природа людини є іншою щодо божественної природи, тим не менше, людина може стати учасником діалогу божественної любові, істинність якого йому відкриває Святий Дух. Ця форма діалогу доступна людям через віру. Саме завдяки вірі людина розуміє істинність діалогу Я - Ти, наближає свою природу до природи Бога.

Інститут фрілософрії імені Г.С. Сковороди НАН України 
Віра посідає особливе місце у філософії М. Бубера. Без віри неможливим стає діалог із Богом, адже коли людина не вірить, вона починає міркувати про Бога. Привносячи віру у свою філософію як головний компонент діалогу буття, філософ-екзистенціаліст порушує гостре питання віри та безвір'я в житті людини. Якщо розкласти це питання вчення М. Бубера на складові, то можна відокремити низку компонентів. Першим компонентом філософії віри буде іï співвідношення із безвір'ям, другим - сама площина віри в діалозі людини та Бога, третім - значення віри в онтології добра та зла.

У своєму творі М. Бубер відокремлює два різновиду віри: віра як довіра, та віра як бездоказове переконання в істинності чогось. У такому поділі віри можна побачити суб' єкт-об'єктне відношення до наявного буття та небуття. Людина може довіряти тому, кого знає, тобто тому, хто входить в коло існування людини в цьому бутті. Але визнання тільки одного буття людині недостатньо, і тому виникає інша віра - віра в істинність того, що існує небуття, того, що може бути за межею пізнання добра та зла людиною. «Ставлення довіри засноване на стані дотику: зіткнення моєї цілісності $з$ тим, до чого я відчуваю довіру. Ставлення визнання грунтується на акті прийняття: моя особистісна цілісність приймає те, що я визнаю істинним» [3, с. 303].

Протилежністю віри у філософії М. Бубера буде недовіра, яка проявляється у відштовхуванні когось за межі кола спілкування, будування діалогу з оточенням на рівні «Я - Воно». Недовіра заважає людині будувати діалог «Я - Ти» і часто-густо є причиною суб'єктивного судження у питаннях моралі. Недовіра штовхає людину на творення зла, адже злий намір не буде виникати до того, кому людина має довіряти.

Протилежністю віри як віри в істинність стає безвір' я. I звісно, що безвір'я стосується того, що виходить за межі знання людиною про буття. Не йдеться обов'язково про заперечення існування чогось іншого, крім зримого буття, йдеться про заперечення існування буття в небутті. Якщо атеїст каже про невіру в Бога, то здебільшого він не вірить не в Бога, а не вірить в Бога як істину. Бо довести, що Бог не є істина, атеїст не може, то він заперечує власне 
екзистенцію Бога, або вимагає доказів буття Бога. М. Бубер звертає увагу на те, що вся історія християнства побудована на постійному намаганні довести існування Бога як єдиної точки опору як сенсу буття, так і взагалі інобуття. Інобуття в християнстві тісно пов'язане $з$ Богом, заперечення останнього веде до руйнації визнання першого, а все разом ставить під сумнів сенс життя людини й тім паче робить безглуздими вчинки людини у призмі добра та зла.

Віра у філософії М. Бубера є дещо більшою, ніж просто визнанням існування Бога низкою релігійних фанатиків. Віра для М. Бубера - це площина виміру спілкування людини з Богом. Тільки людина, що істино вірить, здатна вести діалог с Богом - Ти, тоді як релігійний фанатик буде стояти на позиції віри в Бога - Творця, Бога - Воно, а атеїст заперечувати Бога і визнавати тільки Творця, Воно, Вселенський розум - тобто поняття буття, що легко руйнуються.

М. Бубер вважає, що істина віра в Бога полягає в поєднані довіри та віри бездоказовості в єдину божественну віру. Християне постійно займаються теодицею та доказом існування Бога, вони навіть поклали цей обов'язок на науки, але при цьому вони не відчувають тієї необгрунтованої довіри до Бога, яку мають юдеї. Ранні юдеї довіряли Богу, ввели його в коло свого близького спілкування, але дуже часто відмовлялися від нього, їх охоплювало безвір'я (в Талмуді та Ветхому Заповіті Бог постійно спілкується із пророками, в Новому Заповіті він проголошує волю з неба стосовно Ісуса Христа, але не спілкується навіть з ним). М. Бубер чітко розділяє розуміння віри в християн, та віри в юдеїв. Філософ, досліджуючи тексти Нового Заповіту звертає увагу на протистояння віри та безвір'я як протистояння світла та темряви, добра та зла в християнському світі. «Найбільш глибокий і проникливий тлумачення цих слів, відоме мені, вказує, що у розв'язанні питання про вибір віри або невіри виявляється, якою насправді людина $є$ і якою вона завжди була, але виявляється це таким чином, що рішення приймається тільки зараз і тим відбувається великий поділ між світлом і темрявою» [3, с. 315]. Юдеї не ототожнюють віру з дуалізмом добра та 
зла, цю особливість віри М. Бубер підмічає в християнській релігії, хоча покарання за безвір'я властиво обом релігіям.

Пояснюючи мету створення трактату «Образи добра і зла» М. Бубер зазначав: «Людина знає про хаос і створення в космогонічному міфі, і вона безпосередньо відчуває, що хаос і створення відбуваються і в ньому, але вона не бачить їх разом, вона слухає міф про Люцифера і не помічає його у власному житті. Їй необхідний міст» [5, с. 164]. Цікавим є те, що шукаючи онтологію добра і зла, М. Бубер знаходить її відразу в бутті та небутті. У бутті добро і зло проявляються в макросвіті, тобто світі, яким його уявляє людина, та мікросвіті, яким є сама людина. I тут філософія М. Бубера наближається до кордоцентризму Г. Сковороди. Провівши компаративний аналіз, І. Бергуляк доходить висновку: «Отже, вся філософська система як Григорія Сковороди, так і Мартина Бубера у своєму внутрішньому єстві пронизана антитезами видимого і невидимого світів, що постають у найрізноманітніших ракурсах» [2, c. 163].

Намагаючись 3'ясувати онтологію добра і зла та причетності до їх появи людини, філософ звертається до біблійних сцен появи світу та гріхопадіння. Він обирає біблійську розповідь про порушення божественної заборони Адамом і Свою. М. Бубер говорить про те, що в ній ще не йдеться про становлення людини на шлях зла. Порушення ж заборони Творця, на думку мислителя, означає пізнання світу в його протиставленні, суперечливості. Але якщо «Бог, що стоїть над будь-якою протилежністю, - як зазначає М. Бубер, - оперує з покладеними їм протилежностями добра і зла» [5, с. 167-168], то «оперування протилежностями не дано тому, хто, попри його подобу Бога, бере участь тільки в створеному, а не у творенні» [5, с. 168]. Добро і зло існували ще до появи людини, але вони не могли проростати в буття без допомоги того, хто до нього належить. Фактично добро і зло вітали безтілесними ідеями, доки людина не спробувала пізнати їх для управління ними, адже, згідно з Біблією, людина отримала свободу керувати усім, що створив Бог, крім добра і зла, різниці між якими не існувало до процесу пізнання. Але коли людина встала на шлях пізнання, то зло відокремило- 
ся від добра (хоча до цього моменту проростали разом на одному дереві) і заволоділо людиною. «Пізнання» людини, яка скуштувала плоди забороненого древа, безперечно, відрізняється від божественного, тому що людина «пізнає протиставлення тільки перебуваючи в ньому» [5, с. 168]; тобто через Зло, де він опинився, чи не послухавши Бога, розуміє колишнє своє становище як добро. Отримавши від Бога силу творення, людина почала творити відокремлене добро та відокремлене зло, розуміючи різницю в них тільки після творення. Каїн вбиває Авеля, як вважає М. Бубер, не розуміючи цього акту додійства як прояв зла, оцінка дії відбувається після процесу, а разом приходить й покарання. Саме від цього хотів вберегти Бог людину, попередивши щодо плодів древа пізнання, а після спокуси змієм також заради світу вигнав людей 3 раю в смертне життя, бо тільки так можна було захистити їх від самих себе.

Християнських теологів століттями мучить питання відношення Бога до появи зла. Християнська доктрина заперечує вину Бога в появі зла, але не може відкинути той факт, що зло з'являється ще в Едемі, де змій спокушає Сву плодами $з$ древа пізнання добра і зла. Виникає логічне питання: або Бог-Творець творить не лише, те, що є добрим, як це підкреслюється в Біблії [Бут 1: 1-31], а й те, що є недобрим, тобто злим. У такому разі відповідальність за виникнення зла падає на Бога. Якщо ж заперечувати вину Бога у створенні зла, то тоді під сумнів попадає інша християнська доктрина про божественну всемогутність. Бо інакше треба визнати обмеженість божественних можливостей щодо створення зла. Якщо Бог не є творцем зла, повинен бути той, хто його сотворив, цю провину можна перекласти на людину, але тільки частково, як дію через незнання, чи дію через спокусу. Частково цю провину можна покласти на демона (хоча він згадується тільки в Новому Заповіті). Але навіть якщо припустити, що демон є творцем зла, з'являється відразу два питання: хто сотворив демона і з чого демон творить зло. Повинна існувати ідея зла, з якої проростає зло як намір та як дія. Або ідея добра та зла виникають раніше Бога чи разом з Богом як рівні йому. I все, що Бог творить, він творить 3 ідей, що 
виникли до нього або разом 3 ним, а це вже обмеженість могутності Бога, або Бог принаймні є творцем ідей як ідей добра, так і ідей зла, але, на відмінну від людини та демона, що спокусилися творити зло, за власною волею обмежив свою свободу тільки процесом творіння із добра. Хоча навіть у такому разі божественній сутності повинні бути властиві й добро, й зло. «Панентеїстичний світогляд хасидизму долає розрив між Богом і світом, між злом і добром: в кожній речі представлений Бог, зло $є$ нижня сходинка добра» [8, с. 304].

У християнській дилемі теодицеї М. Бубер вбачає етикомістичну проблему дискурсу Бога і людини. Для прадавніх євреїв, що вірили в Бога, а не розмірковували про нього, не стояло питання його виправдання перед людьми. Добро і зло були частинами божественної екзистенції. Бог для давніх євреїв не був як для християн взірцем абсолютного добра, він жорстоко карає, вимагає покори, але водночас захищає, допомагає, обдаровує благами. Жодна його дія не розглядалась як добра чи зла. «Колишню систему сфер змінив образ протиборчих сил - незалежних і взаємноворожих царств Світла і Темряви. Ми знайдемо їх у всіх системах гносісу - широко розповсюдженого і багатопланового духовного руху, яке захопило розгублених спадкоємців великих культур Стародавнього Сходу й античності, скинуло божество та знецінило творіння» [6, с. 242].

Стосунки Бога й світу в теології М. Бубера можна назвати за властивими особливостями панентеїзмом («світ у Бозі»). Однак світ не відкидали при осягненні Бога. Бога можна осягнути тільки через світ, за допомогою світу. У діалоговій побудові світу, на думку М. Бубера, Бог за своїм єством не може стати Воно, Його не можна об'єктивно зрозуміти або пізнати дослідним шляхом. Із цього випливає, що Бог не є об'єктом доказу, а може бути тільки співрозмовником. Оцінювання дій Бога в призмі добра і зла, аналіз його якостей сприяв об'єктивному відношенню до Бога людиною. Як співрозмовник Бог щезає і в Новому Заповіті вже не розмовляє 3 людиною. Однак усі його діяння християнин намагається підрівняти до власних уявлень про добро, і коли світ змінюється, а разом 3 ним змінюються моральні уявлення людини постає проблема теодицеї 
та перерозуміння дій Бога з точки зору добра. Уявлення про Бога змінюється у людей, і в цих уявленнях божественне світло постійно переломлюється, змінюючи свій напрям, розпадаючись на світлові кольори. Ці кольори осяюють різні релігійні судження, а людина починає визнавати частку розваленого світла за цільне світло.

Таким чином М. Бубер, спираючись на традиції хасизму, тексти Тори, християнські уявлення, формує модель добра і зла як первинні ідеї можливостей, що були створенні Богом ще на початку світу, а головною проблемою сучасної людини вважає не ії гріховність 3 вини Адама та Сви, а втрату діалогу спілкування з Богом на принципі віри.

\section{ЛІТЕРАТУРА}

1. Ахутин А. В. Поворотные времена. СПб. : Наука, 2005. 743 с.

2. Бергуляк І. Подвійність світів у філософії Григорія Сковороди і Мартіна Бубера // Університетські наукові записки: Серія «Філософія». 2012. Вип. 10. С. 154-164.

3. Бубер М. Два образа веры. М. : АСТ, 1999. 592 с.

4. Бубер М. Диалог // Два образа веры. М. : АСТ, 1999. С. 122-161.

5. Бубер М. Образы добра и зла // Два образа веры. М. : АСТ, 1999. C. 162-201.

6. Бубер М. Проблема человека // Два образа веры. М. : АСТ, 1999. C. 202-300.

7. Бубер М. Я и Ты // Два образа веры. М. : АСТ, 1999. С. 24-121.

8. Огурцов А. П., Платонов В. В. Экзистенциально-диалогическая традиция: М. Бубер // Образцы образования. Западная философия образования. ХХ век. СПб. : РХГИ, 2004. С. 285-318.

9. Померанц Г. С. Встречи с Бубером // Два образа веры. М. : АСТ, 1999. С. 5-23.

10. Современный философский словарь // Под ред. В. Е.Кемерова; 2-е изд, испр. и доп. Лондон, Франкфурт-на-Майне, Париж, Люксембург, Москва, Минск : ПАНПРИНТ, 1998. 1064 с. 


\section{REFERENCES}

Akhutin, A.V. (2005). Turning Times. St. Petersburg: Nauka. [In Russian].

Bergulyak, I. (2012). The Duality of the Worlds in the Philosophy of Grigory Skovoroda and Martin Buber. University Scientific Notes: Series «Philosophy», Vip. 10, 154-164.

Buber, M. (1999). Two Images of Faith. Moscow: AST. [In Russian].

Buber, M. (1999). Dialogue. In Two Images of Faith. Moscow: AST. [In Russian].

Buber, M. (1999). Images of good and evil. In Two images of faith. Moscow: AST, 162-201. [In Russian].

Buber, M. (1999). The problem of man. In Two images of faith. Moscow: AST, 202-300. [In Russian].

Buber, M. (1999). Me and You. In Two Images of Faith. Moscow: AST, 24121. [In Russian].

Ogurtsov, A. P., Platonov, V.V. (2004). Existential-dialogical tradition: M. Buber. In Educational samples. Western philosophy of education. Twentieth century. St. Petersburg: RChI, 285-318. [In Russian].

Pomerantz, G. S. (1999). Meetings with Buber. In Two images of faith. Moscow: AST, 5-23. [In Russian].

The Modern Philosophical Dictionary. (1998). Kemerova W. (Ed.). London, Frankfurt am Main, Paris, Luxembourg, Moscow, Minsk: PANPRINT. [In Russian].

\section{Savonova Hanna}

Candidate of Theological Sciences (Ph. D.), Senior Lecturer, Luhansk Regional Institute of Postgraduate Education, Severodonetsk Ukraine, ORCID: https://orcid.org/0000-0003-1790-4770

Ontology of good and evil in the context of philosophy m.buber: search of a dialogue between god and human. 


\section{Abstract}

The article is devoted to revealing the essence of good and evil in the situation of dialogue between God and man according to M. Buber's philosophical worldview. It is noted that the measurement of the world from the position of dualism has found its way in the philosophy of M. Buber through the correlation of communication in the prism of the subject-object contradiction «IYou», «I - It», where I - is an attempt to stick out a man himself a permanent subject over the objects, and the violation of dialogue with God leads to thinking about God from theodicea to atheism. This article uses primary source research directly the works of the philosopher, as well as achievements of other researchers, such as T. Lyncea, A. Outn, A. Ogurtsov, I. Bergolak. The main directions of the article are: analysis of the dialogue structure of the world according to the philosophy of M. Buber; definition of the role of Faith in the system of dialogue between God and man; development of the ontology model of good and evil in the philosophy of M. Buber. In the philosophy of M. Buber distinguishes three types of dialogue, which are passed through the concept of» should «and the concept of» is», that is, a person conducts a dialogue from the position of his own self-acceptance, respectively, as he believes it is worth entering into a dialogue with what is understood as what is relevant to the dialogue. Dialogue with God, man leads from a position of determining who God is in this dialogue, and consequently makes certain claims regarding the rules of communication. In such a dialogue, faith is lost as trust and faith as faith of unsubstantiated. The article States that the ontological model of the world from a position of Christian theodicy is not a dialogue, built by combining two faiths. M. Buber compares two models of communication with God - early Christians and Jews and determines that it was not necessary for early Jews to justify God regarding the creation of evil. This means that God is the Creator and the original source of both good and evil, but only through man evil is separated from good, and acquires its own essence.

Keywords: good and evil, God, dialogue, faith, «I - You», «I-It», dualism. 
ISSN 2078-8142 Multiversum. Philosophical almanac. - 2018. - Issue 3-4 (165-166)

\section{Савонова Анна}

кандидат философских наук, старший преподаватель Луганского областного института последипломного педагогического образования, 2. Северодонеияк, Украина, ORCID: https://orcid.org/0000-0003-1790-4770

\section{Онтология добра и зла в контексте философии М. Бубера: поиск диа- лога между Богом и человеком}

\section{Аннотация}

В статье поднимается и исследуется вопрос определения онтологии добра и зла в философии М. Бубера. Поиск онтологии добра и зла пропускается через три базовые составляющие философии М. Бубера: диалоговое измерение отношений человека с позичии "Я-Тbl», «Я-Оно»; христиане-иудейской спеиифики определения сущности Бога относительно появления зла в мире; раскрытие смысле веры в жизни человека и общении с Богом. Определяется важность налаживания общения человека с Богом с позищии «Я-Ты», когда проблема теодицеи не важна для верующего человека. Раскрывается специфика построения вопроса онтологии зла согласно христианским и хасидским толкованиям. Обращается внимание на ход рассуждения М. Бубера по проблеме онтологии добра и зла и ее отображении в сцене грехопадения человека соответственно до Библейского текста. Делается вывод о творения добра и зла Богом как первичной идеи, а также определении Бога источником добра и зла.

Ключевые слова: добро и зло, Бог, диалог, вера, «Я-Tbl, «Я-Оно», дуализм. 